\title{
Glas in beeld - beeld in glas. Verkondiging in fragment en fragmente van verkondiging ...
}

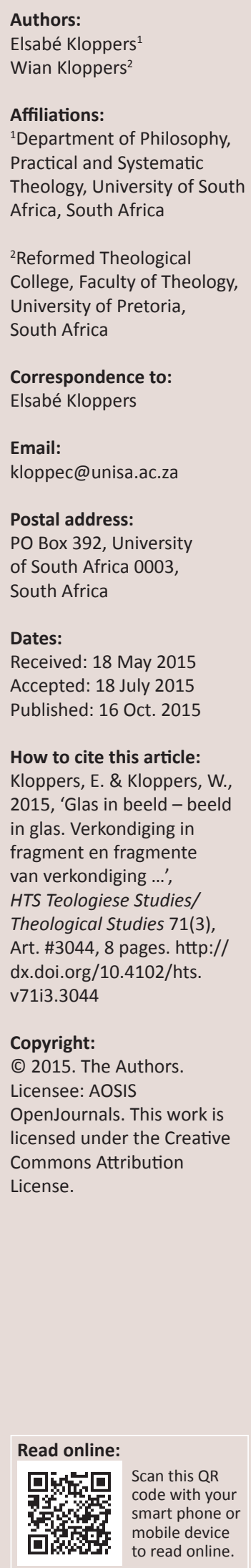

Glass in the image - image in glass. Preaching in fragments and fragments of preaching ... The view that the sermon is an 'open work of art', promoted the awareness that the 'meaning' of a sermon is not fixed, but that possibilities are presented for the listeners to 'assign meaning'. 'Assigning meaning' does not mean something fully ad libitum: 'meaning' is formed within the guidelines of the text from which a sermon stems. Visual works of art could also be based on Biblical texts or stories, analysed and interpreted by the artist. The artist could mould the encounter with the Biblical text into various forms of art, proclaiming the gospel in ways similar to that of a spoken sermon: a work of art could present possibilities for assigning meaning related to faith. In this article the new stained glass windows, symbolically depicting the Liturgical Year, in a Dutch Reformed church in Pretoria, are discussed with a view to the possibilities they present to form part of experience-based religious education in 'bringing home' stories from the Bible and aspects of the Liturgical Year. Also asked is how they could function as visual 'sermons', speaking and communicating the 'Word of God' to the people inside the church, as well as to people on the outside.

'Daar is fragmente wat betekenisvol is oor eeue heen, omdat hulle voleinding net 'n goddelike saak kan wees ...' (Dietrich Bonhoeffer [1944] 1998)

\section{Inleiding}

In die 10 jaar voorafgaande aan die 500-jaar-herdenking van die Reformasie in 1517, in die sogenaamde Reformasiedekade, word daar in die Evangelische Kirche in Deutschland (EKD) elke jaar aan 'n ander tema aandag gegee. In ekumeniese verband oefen hierdie fokuspunte en vierings ook breër'n invloed op ander kerke van die Reformasie uit. In 2015 is die tema Beeld en Bybel. Met dié tema word die geleentheid gebied om na te dink oor die gebruik van die beeld en visuele verkondiging in die teologie, die liturgie, die prediking, verkondiging in kerkruimtes en om kerkgeboue, maar ook op onwaarskynlike plekke, soos in parke, openbare geboue en monumente. In hierdie bydrae word gefokus op die vormings- en verkondigingsmoontlikhede van die nuwe loodglasvensters in die kerkgebou van die Nederduitsch Hervormde Kerk, Pretoria-Oos. Die vensters wat hoofmomente van die Kerkjaar in sestien vensters uitbeeld, is in 2013 en 2014 geïnstalleer.

\section{Die preek as 'oop kunswerk': Die rol van die hoorder}

Die konsep van die 'preek as oop kunswerk' (Martin 1984) het inslag gevind tydens die sogenaamde 'estetiese wending' in die Praktiese Teologie en in die besonder in die Liturgiewetenskap en Homiletiek. Hiervolgens word estetika nie as kunsteorie nie, maar as 'die leer van waarneming' gesien. ' $\mathrm{n}$ Kunswerk is oop daarin dat dit tekens bevat wat aanleiding gee tot waarneming, tot verstaan en tot interpretasie. Soos 'n kunswerk oopstaan vir interpretasie en vulling deur die hoorder of waarnemer, so staan 'n preek oop vir betekenisgewing (Martin 1984:48-49). Dit beteken egter nie dat elkeen kan in-lees wat hy of sy na willekeur wil hoor nie. Die Bybelse teks lê die preek ten grondslag en stel grense. 'Ten grondslag lê', beteken ook nie dat 'n 'boodskap vir die preek' reeds in 'n teks of tekste vasgelê is nie, maar dat dit met moeite vanuit ' $n$ teks of teksgedeeltes ontsluit kan word. 'n Ensemble van eksegetiese metodes en hermeneutiese uitgangspunte wat mekaar aanvul, kan meewerk in hierdie proses van ontsluiting en kan kreatiwiteit in die preekmaakproses stimuleer, soos Schwier (2010:11-29) aantoon. ${ }^{1}$ Hy waarsku teen eensydige metodes wat die moontlikhede van 'n teks verskraal en inperk.

1.Schwier verwys na' $n$ 'kritiese metodepluralisme' wat te midde van die 'vreemdheid van die teks' onder meer ' $n$ blik het op die Bybe as literatuur; wat die rykdom van die Bybelse taal, motiewe, geskiedenisse, beelde, verhale, argumente en literêre strategieë ontgin: as literatuur; wat die rykdom van die Bybelse taal, motiewe, geskiedenisse, beelde, verhale, argumente en literêre strategieë ontgin; van die Bybelse polifonie ondersoek; wat' $n$ oog het vir retoriek en metaforiese strukture. Naas die veelvuldige vorme van tekskritiek het die sosiaal-historiese, kultuur-antropologiese en kontekstuele of samelewings-betrokke ondersoeke wat gerig is op identiteits- en geloofsbegronding, sowel as verandering van die praxis, 'n wesenlike plek. 
Bybelse tekste is inderdaad nie tekste waaroor gepreek word nie: die teks is oop en dit bied die geleentheid vir die eksegeet of prediker om binne hierdie ruimte in te tree, vrae te vra, gesprek te voer, en so tot verstaan te kom. Schwier (2010:26) verwys na Ricœur se siening dat teksinterpretasie in die selfinterpretasie van die subjek uitmond en dat in hierdie proses die subjek - die hoorder, leser of waarnemer daartoe kom om beter te verstaan, anders te verstaan of dalk hoegenaamd eers begin om te verstaan. Verstaan en selfverstaan hang ten nouste met mekaar saam. Die 'estetiese kwaliteit' van 'n teks of kunswerk bestaan daarin dat dit die gespreksgenoot tot selfstandige aktiwiteit aanspoor en tot 'n nuwe beeld van die wêreld bring - soms selfs ' $n$ gans ander beeld van die wêreld en van die self. 'n Preek wat op sigself 'korrek' is en waarin 'geen eksegetiese foute' gemaak word nie, bly onvolledig as dit die hoorder nie uitnooi of uitdaag tot die voortsetting, toe-eiening, of 'voltooiing' van die preek of gesprek nie (Engemann [2002] 2011:171).

Die verstaan van 'n Bybelse teks bly oop, omdat die betekenis van 'n teks 'in elke toekoms nuut ontsluit kan word' (Bultmann 1957/2002:264, in Schwier 2010:13). Die werk van die prediker-eksegeet het ten doel om die teks self tot spreke te laat kom as 'n mag wat in die hier en nou van die teenwoordige tyd en bestaan spreek en wat mense hier en nou kan aanspreek. Die eksegeet-prediker benader'n Bybelse teks met ' $n$ bepaalde verwagting om in die waaragtige soeke na waarheid, geloof, en verstaan iets van die waarheid van die menslike bestaan in die teks waar te neem, en gepaard daarmee die verwagting om in hierdie gesprek met die teks ook in God se gesprek met die wêreld in te tree (Schwier 2010:29). Dit is die grondhouding waarmee die prediker op die kansel behoort te staan: dat hy of sy in die preek nie finale waarhede spreek nie, maar in die 'oop kunswerk', die preek, moontlikhede vir verstaan aanbied en daarmee die ruimte vir die hoorder open om ook in God se gesprek met die wêreld in te tree, iets daarvan te verstaan, en daardeur verander te word.

\section{Verkondiging in beeld - 'n kunswerk as preek}

Die begrip 'oop kunswerk' is ook in die Liturgiewetenskap verder gevoer en op die erediens as geheel betrek. Die erediens bestaan uit 'n kompleks van vorme wat betekenis buite hulleself dra en wat verlede, hede en toekoms in 'n kreatiewe spanning omsluit. Die 'tekens', die oorgelewerde gebruike en rituele in die erediens, die inordening van hierdie tekens en hulle werking in 'n erediens vandag, bring 'n bepaalde spanning teweeg wat die 'singewende proses van waarneming' aan die gang sit (Bieritz 1986:359). Die kunswerkerediens is dus nie volledig oop nie, maar word binne die raamwerk van die waarnemer of hoorder vertolk. Binne die konteks van die erediens word aan die kunswerk-erediens sin gegee (Bieritz 1986:364). Die oorgelewerde handelinge of tekens moet dus nie bloot as ritueel 'gereproduseer' en 'verbruik' word nie, maar moet geleentheid kry om vrygestel word - die tekens moet ruimte open binne die gebeure van die erediens en moet ontvou word in ruimte en tyd. Net só kan hierdie tekens, rituele, gebruike en beelde werklik ervaar en begryp word (Bieritz 1986:373).

Die rol van kuns in die erediens en temas soos die preek of die erediens as kunswerk is reeds vir die plaaslike konteks ontsluit (byvoorbeeld Cilliers 2007 en as Gesamtkunstwerk by Kloppers 2003, in aansluiting by Bastian 1991). Die verkondigingsmoontlikhede van loodglasvensters in die Gereformeerde en Hervormde konteks in Suid-Afrika het in die vakliteratuur oor die algemeen nog min ter sprake gekom - om verstaanbare redes: beelde, afbeelding en loodglasvensters is minder algemeen in hierdie kerke. Naas die kostes verbonde aan wat dikwels net as 'n 'luukse' gesien word, het die 'verbod op beelde' deur die geskiedenis tot hierdie leemte bygedra. Die skepsis teenoor beelde en uitbeeldings en ' $n$ bepaalde gestrooptheid, veral in die kerke van gereformeerde belydenis, is bekend (Stückelberger 2011:219-220). In die na-Reformatoriese tydvak is die gesproke woord as verkondiging oorbeklemtoon. Daar is eksklusief op die gesproke woord staat gemaak en mense is geleer om beelde en simbole te wantrou (Volp 1991:283). Karl Barth beklemtoon byvoorbeeld dat beeldende en simboliese uitbeeldings op geen plek in die protestantse kerkruimte 'n plek het nie. Hy meen dit kan net verwar; daarom sê hy: 'kein Bild und kein Symbol' (Barth 1959:271, in Stückelberger 2011:220).

Vir Luther was die wesensvraag minder belangrik as die konkrete werking van beelde op die waarnemers: beelde en uitbeeldings was onaanvaarbaar wanneer dit bedoel was om mense vanuit magsposisies te beheer. Daarteenoor het hy die waarde van beelde as 'n verkondigingsmedium hoog geag. Die gebruik van beelde en beeldmateriaal het juis die onvermoë van mense erken om oor die Woord van God te beskik (Grözinger 2008:268). Vir Luther was die vraag nie of daar beelde of nié beelde moes wees nie, maar wat die beelde in mense bewerk. Wanneer ' $\mathrm{n}$ mens God se Woord hoor, is dit onvermydelik dat ' $n$ mens in die geestesoog 'n eie beeld vorm. Die 'resepsievryheid' van die waarnemer is dus reeds deur Luther erken. Beelde is legitiem waar dit meewerk om die bevrydende krag van die Woord van God te versterk. Die estetiese kriterium vir die legitimiteit van beelde lê dus in die bevrydende dialektiek van woord én beeld: dat beide gesamentlik nuwe perspektiewe ontsluit, dat daardeur 'n elementêre ervaring van vryheid moontlik gemaak word, en veral dat 'n blik op die waarheid moontlik word (Grözinger 1991:52). Hierdie voorwaarde is die kwalitatiewe kriterium waaraan Luther die beelde onderwerp het. Die aanspraak van die Reformatoriese kerke om 'Kerk van die Woord' te wees beteken dus nié om iets te sê oor die medium wat gebruik word nie, maar om die grond, die uitgangspunt en die onderwerp van verkondiging, van geloofskommunikasie te beklemtoon (Kloppers 2003a).

In die gemeenskap van die gelowiges wat hulleself as 'Kerk van die Woord' verstaan, word nie net 'met woorde' gepraat nie - alle vorme van uitbeelding en verbeelding wat in die gemeente na vore kom, kan 'Woord' wees. 'n Kunswerk kan ook as verkondiging, as 'preek' ondersoek word. Sake 
wat in dié verband ter sprake kom, is die verhouding tussen die kunstenaar, die Bybelteks en die kunswerk; ook die verhouding tussen die kunswerk (of die kunstenaar), die vertolkers of waarnemers en die Bybelteks. In watter verhouding staan die vertolkers tot die kunswerk, watter moontlikhede word gebied dat die Bybelteks deur middel van die kunswerk 'gehoor' en 'geloof bewerk' word? Watter tekens speel mee? Belangrik is ook die assosiasies wat na vore geroep word in die ontmoeting met die kunswerk (Ulrichs 2013:13). Soos met die lees van 'n Bybelteks of 'n gedig kan 'n direkte werking van die kunswerk ervaar word, maar 'n kunswerk kan ook eksegeties vanuit die Bybel- en ander wetenskappe ondersoek word. Dieselfde aspekte as wat vir die omgang met ' $n$ Bybelteks genoem is, geld vir die 'kunswerk wat preek' - met vrae soos die volgende: watter eksegetiese spanning kom na vore, waarvan getuig die kunswerk, wat kan in die tussenruimtes gelees en gehoor word? Wat word verswyg? Watter moontlikhede word vir geloofskommunikasie geopen? Kunswerke is outonome subjekte. Kunswerke spreek in sigself en kan in sigself ook preek. Soos met Bybelse tekste word daar nie oor kunswerke gepraat of gepreek nie, maar die gespreksgenoot tree met die teks of kunswerk in ontmoeting en probeer hoor wat dit sê. Die kunswerk bied die moontlikheid vir betekenis- en singewing wat die gespreksgenoot tot totaal nuwe insigte kan bring.

In die gesprek met die Bybelse teks (as kunswerk) is die prediker die 'herskeppende kunstenaar' wat telkens as persoon met die eie teks as kunswerk op die kansel ('podium') staan en goed sigbaar en hoorbaar die kunswerk 'aanbied'. Tussen die beeldende kunstenaar en die kunswerk wat verkondig, is per definisie meer afstand. Die kunswerk spreek in die afwesigheid van die persoon van die kunstenaar. Die kunstenaar as eksegeet en as prediker is ook 'herskeppende' kunstenaar wat in die kunswerk sy of haar eksegese van Bybelse gedeeltes en sy of haar ontmoeting met die teks, in samevattende en verdigtende vorms, weergee. Daarmee saam word ook iets van sy of haar eie geloofservaring en ontmoeting met God vergestalt. Net soos met die prediker in woord lê die 'betekenis van die preek' nie in die hande van die kunstenaar nie - die kunstenaar hou nie 'n 'sleutel tot verstaan' nie. Beeld, kleur, lyn, motief, komposisie en suggestie word gebruik om 'inhoud' oor te dra, moontlikhede te suggereer, betekenisgewing moontlik te maak, maar die moontlikhede is oop sodat elkeen hom of haar in die ruimte, die ruimtes en die tussenruimtes kan inlaat, op 'n unieke manier hoor wat die kunswerk 'sê', en in die proses van hoor en verstaan self die kunswerk-preek kan voltooi. Die gelowige (en ook die ongelowige) wat in die oop ruimtes intree en met die kunswerk in gesprek tree, kom ook in die sfeer van God se gesprek met die skepping, ervaar en bely dat God se Gees die 'herskepper' en 'interpreteerder' van die kunswerk word; hoor die verkondiging deur die kunswerk en ontmoet God daardeur.

In 'n artikel oor die nuut geïnterpreteerde Pietà deur die skilder Boris Anisfeld wys Kloppers (2013) uit dat woorde dikwels juis te kort skiet ten opsigte van die visuele verkondiging deur 'n kunswerk, en dat die ryk geskakeerde betekenismoontlikhede eerder ingeperk word deur die verduidelikende woord. Die gesproke preek het boonop 'n 'vlietende dimensie'. Dit vind eenmalig in die erediens plaas. 'n Kunswerk soos loodglasvensters het egter voortgaande verkondigingsmoontlikhede. Tydens die erediens het dit 'n intertekstuele werking saam met al die ander 'tekste' in die erediens. Gedurende die week kan dit egter ook 'n bepaalde werking hê wanneer iemand die kerkruimte binnekom. So gesien, het kunswerke 'n verkondigingswaarde wat die gesproke verkondiging in reikwydte kan oortref. ${ }^{2}$

\section{Die kategetiese en vormende funksie van waarneming en ervaring}

As 'preke in beeld' het kunswerke soos loodglasvensters verkondigingswaarde. Dit het egter ook kategetiese of vormende waarde, daarin dat lidmate daardeur toegerus word en opkomende geslagte in die hoofmomente van die Christelike geloof gevorm word. Godsdiensonderrig is in die afgelope dekades in baie skole in Suid-Afrika ingekort. Ook erediensbywoning het afgeneem, wat tot gevolg het dat kinders minder deur kategetiese onderrig op Sondae bereik word. Alternatiewe metodes vir die verwerwing van kennis, vir inlywing in die simbole van die geloofsgemeenskap en nuwe wyses waarop die geloof oorgedra kan word, is dus noodsaaklik.

Die rol van ervarings-geörienteerde geloofskommunikasie, ervaringsgerigte waarneming en die performatiewe aspek in religieuse vorming word geruime tyd reeds erken (byvoorbeeld Klie \& Leonhard 2008; Wegenast 1991). Die oordra van die geloof is gerig op die kommunikering van 'n simboliese werklikheid en op singewing. Nie slegs die kognitiewe dimensies speel 'n rol nie, maar ook die spirituele, die estetiese, die performatiewe en die emotiewe. Die ervaring van die werklikheid is onontbeerlik. Dit wat konkreet en prakties ervaar word, is dit wat toegeëien en deel van 'n mens se verwysingsraamwerk word. Die rol van die gepaste beeld en die verstaan van die visuele behoort 'n onontbeerlike plek in die toerusting en opbou van lidmate én predikante te hê (Kloppers 2003b). Vanuit die kerklike pedagogiek word die waarneming, verstaan en ontsluiting van kerkruimtes uitgebreid bespreek in Rupp (2006) en ook deur Naumann (2013), wat kerkgeboue en die kerkjaar met mekaar in verband bring.

Die ervaring van loodglasvensters binne 'n kerkruimte, maar ook van buite waargeneem - dus met'n missionêre dimensiekan 'n wesenlike rol speel om verskillende aspekte van die Christusboodskap, van die geloofbelydenis en die geloofslewe, uit te dra. Dit kan ook bydra om die bewussyn vir die tye van die Kerkjaar te versterk as tye waarin en waardeur jongmense en nuwelinge in die geloof ingelei word,

2.Rembrandt was ' $n$ meester in die kunswerk as preek. Hy het homself soms in kunswerke geplaas, soos om 'teenwoordig te wees' op die toneel van die kruisiging kunswerke geplaas, soos om 'teenwoordig te wees' op die toneel van die kruisiging
en het só deel van die ontmoetings-, belydenis-, én verkondigingsgebeure geword en het só deel van die
(Kloppers 2006:8-11). 
koinonia bevorder word, mense vertroos en heling bewerk word, die kerk se dienswerk geanker word, die belydenis gedra word, die vieringskarakter van die erediens versterk word, die ekumeniese karakter van die erediens versterk word en die geloof ook na buite uitgedra en verkondig word (Kloppers E 2010). Tot 15, 20 jaar gelede is die 'hooffeeste', soos Kersfees en Paasfees in die Afrikaanse susterkerke gevier, maar as losstaande entiteite en nie as vieringe binne 'n breër geheel wat ' $n$ bepaalde verband met mekaar het en saam 'n bepaalde struktuur vorm nie. Die afgelope dekade of twee het 'n groter bewussyn vir die Kerkjaar in baie gemeentes gekom, maar baie lidmate en predikante het nié met 'n bewussyn vir die Kerkjaar groot geword nie; daarom bly voortgaande toerusting nodig.

\section{Die loodglasvensters in die Hervormde Kerk Pretoria-Oos}

Die ervaring van 'n kerkruimte en alles wat daarin waargeneem word, werk wesenlik mee in die ervaring van 'n erediens (Hermelink 2007:12; Raschzok 2003 en PohlPatalong 2011:173-178 vir onlangse empiriese studies). Wat in 'n kerkruimte waargeneem word, 'spreek' voordat 'n enkele woord nog gesê is. Dit bepaal mense se stemming en kan mense se ingesteldheid ook daadwerklik verander - van negatief na positief of omgekeerd.

Die 'gewone' vensterruite in die kerkgebou van die Hervormde Kerk Pretoria-Oos, gepaard met die strak lyne en minimalistiese interieur, het min bygedra tot 'n dimensie van visuele verkondiging in die kerkruimte. As voorbereiding tot die daarstel van loodglasvensters skryf die gemeente se predikant, Hannes van der Merwe (2013:25), in die gemeente se kwartaalblad oor die loodglasvensters in die katedrale in Europa en die atmosfeer van aanbidding wat dit teweeg bring, en spreek die wens uit dat daar ook in dié gemeente se kerkgebou loodglasvensters kan kom wat 'tot die gemeente se aanbidding' kan bydra. Vroeg in 2013 word besluit om loodglas-ontwerpe in die sestien vensters van die kerk aan te bring - op voorwaarde dat dit net met skenkings en insamelings befonds kon word. Die voorstel het behels dat die ontwerpe sestien hoofmomente van die Kerkjaar simbolies voorstel. Wian Kloppers ${ }^{3}$ is genader om die ontwerpe van die 16 vensters te doen en Fanus Boshoff is as glaskunstenaar genader. ${ }^{4}$

Die werk aan die ontwerp is aangepak vanuit die beginsel van verkondiging in beeld: beeld in glas, glas in beeld. 'n Eerste vraag in die oorweging van die ontwerp sou wees of moderne, abstrakte ontwerpe waar net van kleur, lyn en suggestie gebruik gemaak word, 'n moontlikheid sou wees. Vanaf 2005 tot 2012 is byvoorbeeld 'n reeks van nege vensters

3.In die gemeenteblad is dit gemotiveer en is hy beskryf as' $n$ kenner 'van simboliek en die kerklike jaar' (Van der Merwe 2013:25). Dit spruit onder andere daaruit dat hy as redakteur van die gesinstydskrif Konteks'n vormende invloed uitgeoefen deur vana redakteur van die gesinstydskrif Konteks ' $\mathrm{n}$ vormende invloed uitgeoefen deur vana 2004 die tydskrif volgens die Kerkjaar in te rig en te sorg dat verskillende temas opsigte van simboliek en die Kerkjaar, byvoorbeeld Kloppers (2003c).

4.Volgens Boshoff (2014:11) was hy 'verbaas' om deur 'n Hervormde Kerk genader te word - in die 22 jaar dat hy by die skepping van liturgiese loodglas betrokke is, was die aanvraag daarvoor nog slegs by die Katolieke en Anglikaanse kerke. van die kunstenaar Johannes Schreiter in die Peterskirche in Heidelberg ingebou (Schwier 2014). Die ontwerpe is abstrak, en alhoewel die naam van elke venster 'n aanduiding gee, is die ontwerpe volledig oop vir individuele interpretasie. Neem 'n mens die lang tradisie waarbinne dié kerk staan, in ag - as die oudste kerkruimte in Heidelberg, die eerste keer in 1196 ingewy, asook dat dit nie 'n gemeente binne 'n geografiese gebied is nie, maar 'n kerk vir veral die professore en studente van die Universiteit Heidelberg is, dan beteken dit dat daar heel anders gedink kon word, omdat die konteks, die gebou, die agtergrond, die gerigtheid, die samestelling van die gemeente, die verwysingsraamwerk van die lidmate - veral ook ten opsigte van die Kerkjaar en verder ook die beskikbare middele, totaal verskil van dié van die Hervormde Gemeente Pretoria-Oos.

Die gemeente Pretoria-Oos wil uitgesproke 'n gesinskerk wees, waar die gemeente en die gesin binne die breër gemeenskap funksioneer en waar ook vrye ruimte vir kinders moet wees. Hierdie uitgangspunt en aard van die gemeente het dus 'n wesenlike rol gespeel in die keuse van die ontwerpe. In plaas van volledig abstrakte ontwerpe is dus gekies vir herkenbare Bybelse temas, ${ }^{5}$ waardeur kinders ook makliker toegang tot die Bybelse verhale kan kry en waardeur die verskillende tye van die kerkjaar sigbaar en verstaanbaar uitgebeeld kan word. Soos 'n preek nie net ' $n$ 'letterlike' weergawe van ' $n$ teks is nie, maar die prediker se interpretasie in gesprek met die Bybelse woord wat tot 'n 'kunswerk-preek' gevorm word, so is die ontwerpkunstenaar ook 'herskeppende' kunstenaar wat in die kunswerk sy of haar ontmoeting met die teks weergee. In gesprek met die teks is die Bybelse gegewens geïnterpreteer en in nuwe ontwerpe nuut weergegee. Die uitbeeldings van verhale en gebeure is in jukstaposisie of in kontrapunt met mekaar geplaas, met mekaar verbind, of loop oor in mekaar. Verskeidenheid en variasie is verkry, maar ook binding en eenheid. Die uitbeeldings bied die geleentheid vir gesprek, daag die gespreksgenoot uit om nuut te dink en maak nuwe interpretasies van ou waarhede moontlik. Die vensters straal ook'n vriendelikheid uit - soms selfs 'n speelsheid. ${ }^{6}$ Te midde van die angs, lyding en onsekerheid in die wêreld is die Evangelie wat ons verkondig 'n blye boodskap. Waarom sal mense na die erediens kom as hulle nie ook hierdie blydskap kan sien en ervaar nie? In die bespreking van die Heilige Gees-venster van Johannes Schreiter in die Peterskirche in Heidelberg verwys Sundermeier en Schwier na die vreugde en troos wat deur die venster uitgestraal word en vra:

Gewinnt nicht das Glauben und Beten im Gottesdienst Kraft, wenn es fröhlich geschieht und in Treue zu Gott und den Menschen? Erfahre ich nicht Trost, wenn ich Geduld,

5.Kerkvensters wat veral in die Tweede Wêreldoorlog beskadig is, het gelei tot ' $n$ groot aantal nuwe loodglaswerke en geskilderde glas, veral in die 1950's en 1960's. Hierdie ontwerpe is oorwegend modern. In die laaste dekades van die twintigste eeu het egter in meerdere mate ook weer rekonstruksies van ouer glaswerke en meer konvensionele Bybelse temas in weer rekonstruksies van ouer glaswerke en meer konvensionele Bybelse temas in die plek van abstrakte glaskunswerke na vore gekom. http://de.wikipedia.org/wiki/Glasmalerei (webwerf besoek 15 Desember 2014.) In 'n tydvak waar bekendheid met Bybelse temas al minder veronderstel kan
word, kan konvensionele Bybelse temas toenemend 'n plek verkry.

6.Die erediens word ook as 'spel' gesien. Heimbrock (1993) bespreek die erediens as die 'speelruimte van die lewe' - met die dubbele implikasie van lewe en nuwe lewe, dus Lewe. 
Freundlichkeit und Güte spüre und weitergebe? (Sundermeier en Schwier 2013:68)

Volgens die predikant van die gemeente het die projek lidmate aangegryp en het hulle 'n visie van 'n 'nalatenskap aan volgende geslagte' beleef (H. van der Merwe 2014:6). Die vensters is deur die gemeente aanvaar as deel van hulle visie tot gemeente-wees en gemeentebou. Met die onthulling van die vensters is interpretasiemoontlikhede voorgestel en in verskillende uitgawes van die gemeenteblad is aangedui waarom sekere motiewe gekies is. Volgens 'n lidmaat van die gemeente, teologiestudent Kristy van der Merwe (2014), het dit meegebring dat die simboliek van die vensters 'n konstante besprekingspunt in die gemeente geword het. Sy meen gemeentelede het meer aktief begin deelneem deur ook hul eie interpretasies te vorm en daaroor te praat. So het die vensters volgens haar ' $n$ transformasie in die gemeente gebring wat dieper gaan as net die estetiese: die gemeente is daardeur aangespreek en geïnspireer om meer skeppend en aktief aan die erediens as geheel deel te neem.

\section{In ontmoeting en gesprek met die vensters}

Die navorsing, beplanning en werk aan die vensters was omvangryk en het oor 2 jaar gestrek: sestien vensters, elk met nege ruite wat vanaf sit-hoogte tot teen die dak strek, met 144 panele en meer as 17000 stukkies glas. Bykans 'n ton lood is gebruik! Dit het wiskundige vermoë geverg om die ontwerp bykans matematies uit te werk en alle onderdele (en simboliek) in geheel bymekaar te bring. Die werk deur die loodglaskunstenaar en sy span van drie, wat elke stukkie glas individueel gesny en in lood verpak het, was indrukwekkend. Ook die samewerking tussen ontwerper en glaskunstenaar was inspirerend en verrykend.

Die reeks vensters, agt aan weerskante van die kerkgebou, verbeeld die Kerkjaar in vier siklusse: Kersfees, Paasfees, Pinkster en Koninkryk. Elke kant bestaan uit sewe vensters met die agtste venster telkens van die sewe geskei deurdat dit deel van die liturgiese ruimte uitmaak. Hierin is verskeie vlakke van simboliek opgesluit: die sewe vensters vorm simbolies 'n eenheid op grond van die betekenis wat aan die syfer in Bybelse tekste verleen word. Dit dui op volmaaktheid of volledigheid. Die ontwerper moes met hierdie argitektoniese gegewe rekening hou en dit in die simboliese vergestalting benut. Die Goeie-Vrydag-venster en die Opstandingsvenster bevind hulle in die 'liturgiese ruimte', ietwat verwyder van die 'kerkruimte'. Dit hou die besondere verkondigingswaarde in dat die nagmaaltafel, wat in hierdie ruimte staan, hierdie verkondigingspole met mekaar verbind: Christus se versoenende sterwe en sy bevrydende opstanding. Ook die doopvont, wat binne hierdie ruimte staan, verkondig elke Sondag die boodskap wat deur hierdie twee vensters verbeeld word: die dood en opstanding deur die doop - maar ook die inlywing in die geloofsgemeenskap, die Kerk van Christus.
Die begin van die Kerkjaar, die Kerssiklus, waar opnuut gewag word op die Verlosser wat moet kom, word uitgebeeld in die suidelike aansig. In die Advent- en Epifanievensters simboliseer kerse die mens wat hoopvol op die Lig wag, en dit daarna as ligdraers na die wêreld uitdra. Die vensters weerspieël die kosmiese gebeure van die geboorte van 'n nuwe ster wat 'n nuwe bedeling aankondig. Hierdie tema word in die vyftiende en sestiende vensters opgeneem om op die eskatologiese hoogtepunt te dui: God se toekoms. Die kosmiese gebeure word deur sirkel-konstellasies, verteenwoordigend van planete, maar ook as simbool van God se volmaakte teenwoordigheid en werking, verbeeld. Die reënboog as simbool van God se genade in hierdie twee vensters, asook die laaste twee van die Koninkrykkring, bring binding in die geheelverkondiging. Die uitbeeldings in die Kersfees- en Doopvensters is meer konkreet om die boodskap van Christus se herkenbare menswees in hierdie wêreld te vergestalt. Teenoor die Adventvenster, waar die lyn van onder na bo loop, vertoon die Kersfeesvenster 'n prominente lyn van bo na onder. Dit dui op die menswording van Christus. Die Doopvenster se lyne kom van bo en van onder, en ontmoet in die middel. Hierdie motief van lyne word in die Hemelvaartvenster verwysend opgeneem. Die Doopvenster dra die simbole van God se teenwoordigheid (volkome sirkels) en die Heilige Gees (duifmotief), te midde van 'n aardse doop deur 'n mens se hand, in 'n onvolmaakte wêreld (gebroke en onvolkome sirkels). Hierdie simbole bind aan dié van die Epifanievenster en dien as saambindende simbole van die hele Kerssiklus.

Na die Epifanievenster volg die vier vensters in die Paassiklus. Die eerste lydensvenster verbeeld die werklikheid dat Jesus Christus sedert sy geboorte lydende kneg is - daarom word beelde en kleure uit die Kersfees- en Doopvenster in 'verdonkerde' toon herhaal. Die Adventster dra reeds inherent die kruis, maar word hier eers duidelik sigbaar. In die 'verdonkerde Adventster' is die lyn van lig wat met die kruis verbind, egter duidelik sigbaar. In die twee ruite waarin Jesus se worsteling met die bose verbeeld word, is hierdie lyn van lig gebuig. Dit dui op die stryd om die lig van Christus af te neem. Die sekerheid van die liglyn wat deur die kruis na die opstanding en hemelvaart loop, dui op oorwinning oor die bose. Hierdie uitbeelding word dus eers in die Opstandings- en Hemelvaartvensters voltooi.

In die venster wat Palmsondag uitbeeld, word getoon dat Jesus homself nie as 'n aardse koning sien nie, maar as 'n dienaar wat met kinders op sy skoot sit en afbuig om na die geringstes om te sien. Hierdie venster se meer realistiese beelde verkondig dat dienaar-wees nie ' $n$ 'geloofs-abstraksie' is nie, maar die werklikheid wat Christus op aarde tussen gewone mense kom voor-leef het. Die derde lydensvenster verbeeld die gebeure rondom die instelling van die Nagmaal, die worsteling in Getsemane en die verraad. Ook bewustelik realisties - die skokkende werklikheid dat die verraad vanuit die 'vertroude' binnekring kom, word getoon deur die ruimte waarbinne dit plaasvind: 'n kerkruimte waar die kerkvensters in die agtergrond sigbaar is. 
Op die Goeie-Vrydag-venster is die somber strale van die doringkroon verbind met die gebeure van die dra van die kruis. Die liglyn is 'n oomblik gebroke, maar reeds by die afhaal van die kruis begin die liglyn weer na bo strek in die sekerheid van die oorwinning oor die bose. In die lydenstyd-vensters word die sirkel as simbool van God se volmaaktheid deur 'n ellips vervang. Dit verbeeld God se afbuig aarde toe in die gestalte van sy Seun. In die GoeieVrydag-venster se laaste twee ruite, die donkerste twee, word die driehoek verbreek wat die Drie-eenheid verbeeld,sprekend van die vraag: Vader, waarom het $U$ my verlaat?

Die noordelike aansig begin met die Opstandingsvenster. Hierdie venster is in die liturgiese ruimte, in kontras met die Goeie-Vrydag-venster aan die oorkant. In hierdie venster word die laaste beeld van die Goeie-Vrydag-venster, dié van die dood, die donker geslote graf, deurbreek deur die Lig. Die venster verhelder geleidelik opwaarts totdat die boonste twee ruite die volle ligglans van die oorwinning oor die dood uitstraal (Figuur 1).

Die Hemelvaartvenster toon die oorwinning waarmee Christus hemel en aarde versoen. Die lyne van bo en van onder waarna in die Kerssiklus verwys is, kom dus hier bymekaar. Die simboliese kleure van die Kerskring word hier herhaal as beeld van die voltooiing van Christus se werk op aarde. Die liglyn wat geboë en selfs onderbroke deur die lydenstyd geloop het, loop hier met kragtige sekerheid na bo waar dit op 'n verblindende poort van lig uitloop. Die volkome sirkel en abstrakte duif-motief dui op die Drie-eenheid.

Die Pinkstervenster straal van lewe en vuurkrag en verbeeld die ryk skakerings van God se genade. Die simbole van kuns en musiekinstrumente dui op die verskeidenheid gawes en die nuwe lewensmoontlikhede wat die Heilige Gees gee. Die lyne en beelde is dinamies en vloeiend en die mensefigure 'versmelt' met die 'vlammende tonge'. Die mensefigure as 'brose kerse' in die Kerssiklus het nou in vlammende figure verander - mense 'bemagtig' deur God se Gees. Die Drie-eenheid-venster gee ' $n$ fragment weer van God se self-

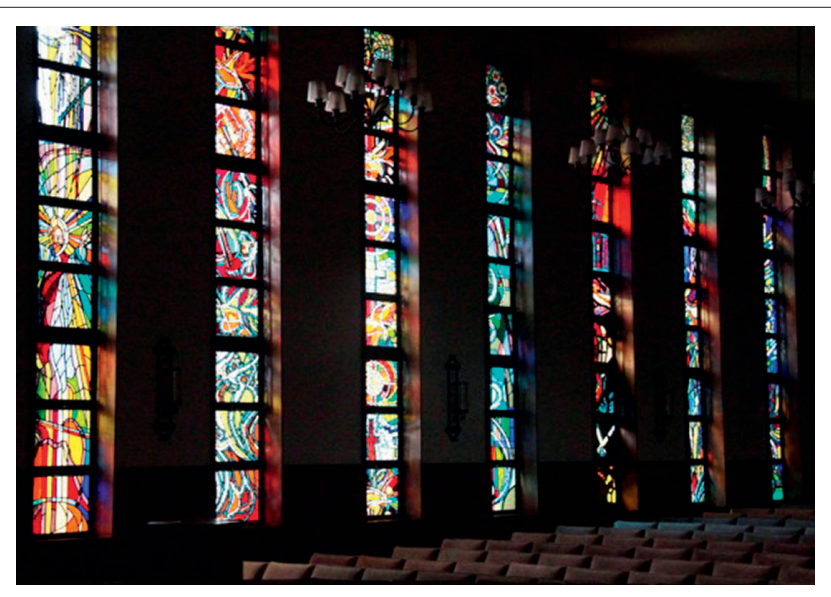

Bron: Foto geneem deur Wian Kloppers

FIGUUR 1: Die noordelike aansig met die Hemelvaart-, Pinkster- en Koninkrykvensters. openbaring, deur die volkome sirkel vir die Vader, die kruis vir die Seun en die duif as simbool van die Heilige Gees. Die simbole word drie maal, telkens in drie ruite, herhaal. Hierdie 'drie-dubbele' drie-eenheid in drievoud weerspieël wat menslik onmoontlik is: om die wese van God in beeld óf woord uit te druk.

Die Koninkryk-siklus weerspieël iets van die verhaal van God se pad met die mens: deur die donker oomblikke van menslike martelaarskap ter wille van die Evangelie; die mens se pogings tot deelname aan God se koninkryk (gebroke lyne, distorte sirkels) en God se herskeppende genade waardeur die mens deel kry aan die oorwinning van die Lig oor die donker. In hierdie uitbeelding staan die Kerken-wêreld-venster (geloofsmartelaarskap) in skril kontras met die omliggende vensters. Dit laat minder lig deur as die Goeie Vrydag-venster. Dit beeld die mens se verduisterende optrede uit: die gelowiges (ook die kerk) is nie deursigtig nie, laat God se lig nie verder skyn nie, staan dit selfs toe. 'n Liggie wat bly brand, dui op die vashou aan Christus se kruis (onderste vier ruite). Die donker word deur God se lig deurbreek - die strale breek die toekoms hoopvol oop.

Die Eskatologie-vensters (Skepper en herskepping) bied die finale oploop tot die klimaks en die 'voltooide beeld'. Die omvang van die gebeure wat by die geboorte van 'n nuwe Ster begin (waarmee die Kerkjaar in die Advent-venster ingelui word), word in die beelde van die Eindtyd herhaal: die reënboog as simbool van God se ryk geskakeerde genade en die mens se hoop op die toekoms, nou in deursigtige kleure; trompette wat die einde van die gebroke aardse bedeling aankondig; 'n nuwe stad uit die hemel - skoon soos 'n bruid; helder planete en volkome sirkels wat daarop dui dat 'n volmaakte, omvattende dimensie aanbreek, waar God alles in almal sal wees.

\section{Lewe uit lig, verkondiging uit fragment}

Die loodglasvensters is oop kunswerke wat op God en die geloof dui. Die mens kan God net ten dele ken - net in 'brokstukke'. Ons het perspektiewe op God en die geloof, wat bepaal word deur die hoek waaruit 'n mens kyk. Niemand beskik oor God nie - dit het Luther in sy uiteensettings oor beelde in die kerk geleer. God ontmoet ons - in tekste, in preke, in gebeure en in mense, maar ook in beelde, kleure en perspektiewe. Soos gesproke beelde (metafore en preke) staan sigbare beelde, ontwerpe, kleure en lyne oop vir interpretasie en wil aanleiding gee tot verstaan (Figuur 2).

Soos kunswerke oopstaan en mense uitnooi om met hulle in gesprek te tree, so nooi ook die loodglasvensters mense uit om gespreksgenote te word. Loodglasvensters het egter die lig van buite nodig om tot hulle volle reg te kom. In dié sin is hulle dus nog meer 'oop' - só konkreet dat die lig deur hulle straal; so oop dat dit moontlik is om deur hulle te kyk en ander, nuwe perspektiewe op die werklikheid te kry, soms 'n totaal nuwe beeld van die wêreld - en van die 


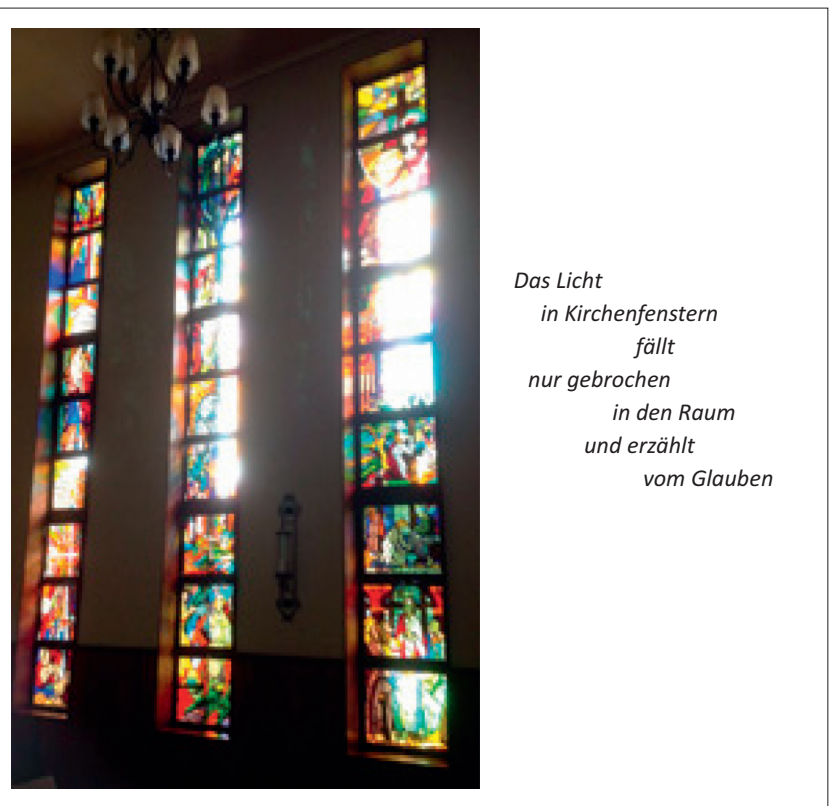

FIGUUR 2: Gedig deur Elsabé Kloppers (verwerk uit Schwier 2014).

hemel - te vorm. So funksioneer die kunswerke inderdaad op dieselfde vlak as die preek. Francisca du Randt (2013:4) gee 'n sprekende beskrywing na aanleiding van haar ervaring met die inwyding van die eerste vier vensters. Sy beskryf die vensters as ' $n$ preek in glas en lig: 'Bedags val die lig na binne, waar ons bymekaarkom in aanbidding; saans straal die lig van binne na buite, om 'n donker wêreld aan die lig van Christus te herinner'.

In geen ander kunsvorm word so 'n hoë kleurintensiteit en soveel kontras in helderheid verkry as in 'n deursigtige glasbeeld nie. Die lig gee die vensters lewe en maak hulle tot dit wat hulle bedoel is om te wees: kunswerke wat leef, kunswerke wat straal, kunswerke wat verkondig. Verder gevoer, word die vensters simbool van ons lewens en die geloof: die ewige Lig gee ook aan ons lewe, verhelder ons, helder ons op, steek die geloof in ons aan. Die geloof kom nie uit onsself nie. Die ewige Lig maak ons wat ons is: lewende kunswerke - kunswerke wat die Lig uitstraal, dit verder moet dra en wat help om ander 'n nuwe perspektief op die lewe en 'n nuwe ervaring van die werklikheid te gee. Daarom moet ons ook oop wees vir die ewige Lig, en deursigtig word.

Deursigtigheid en oopheid dui egter ook op verwondbaarheid, op breekbaarheid. Hier kom die lood ter sprake. Die funksie van die lood is om die stukkies gebroke glas tot ' $n$ eenheid te verbind - 'n eenheid wat veel sterker is as 'n enkel stuk glas van dieselfde grootte. Saamgebind, in koinonia, gebind deur die 'lood' as sement van liefde, is die gemeenskap van gelowiges veel sterker. Die brokstuk, die fragment, die simbool van breekbaarheid en gebrokenheid, word in die kunswerk die simbool van krag, van duursaamheid, van ewigheid. Fragmente van glas word bymekaar gebring tot 'n eenheid wat'n groter eenheid weerspieël. In die verbinding van die brokstukke word perspektief en nuwe perspektief verkry. Tog bly die dele, die fragmente sigbaar - dele wat getuig van die geheel, van dit wat 'n mens hier nooit volledig kan sien nie, maar waarop 'n mens kan hoop; fragmente wat verkondig - verkondiging in fragmente, maar fragmente wat wys op volledigheid, op die volmaakte wat kom.

Nou sien ons beeldein glas en glas in beeld,'ngefragmenteerde beeld, maar as die volmaakte kom, sal ons van aangesig tot aangesig sien, sal ons ervaar hoe die fragment van ons lewens inpas in die groot loodglaswerk ...

... en dit voltooi.

\section{Erkenning Mededingende belange}

Die outeurs verklaar dat hulle geen finansiële of persoonlike verbintenis het met enige party wat hulle nadelig kon beïnvloed in die skryf van hierdie artikel.

\section{Outeursbydrae}

E.K. (Universiteit van Suid-Afrika) was verantwoordelik vir die deel oor die homiletiek en W.K. (Universiteit van Pretoria) die deel oor die loodglasvensters. Beide dele is geïntegreer en verwerk deur die outeurs.

\section{Literatuurverwysings}

Barth, K., 1959, 'Zum Problem des protestantischen Kirchenbaus', Werk 46(8).

Bastian, H., 1991, 'Auge und Ohr, Sehen und Hören: Eine Revision theologischer Mediendidaktik' in D. Zilleßen, S. Alkier, R. Koerrenz \& H. Schroeter (Hg.), Praktisch-theologische Hermeneutik, Ansätze-Anregungen -Aufgaben, pp. 339352, CMZ, Rheinbach-Merzbach.

Bieritz, K-H., 1986, 'Gottesdienst als "offenes Kunstwerk"? Zur Dramaturgie des Gottesdienstes', Pastoral-Theologie 75, 358-373.

Bonhoeffer, D., [1944] 1998, Widerstand und Ergebung. Briefe und Aufzeichnungen aus der Haft, Gütersloher Verlagshaus, Gütersloh.

Boshoff, F., 2014, 'My loodglas-ervaring met die gemeente Pretoria-Oos', Polsslag 14, 11.

Bultmann, R., 1957, 'Ist voraussetzungslose Exegese möglich?', in R. Bultmann, 2002, Neues Testament und christliche Existenz. Theologische Aufsätze, uitgebrei deur A. Lindemann, (Red.), pp. 258-266, Mohr, Tübingen.

Cilliers, J.H., 2007, Binne die kring-dans van die kuns: Die betekenis van estetika vir die Gereformeerde liturgie, Sun Press, Stellenbosch.

Du Randt, F., 2013, 'n Preek in glas en lig', Polsslag 10, 4.

Engemann, W., [2002] 2011, Einführung in die Homiletik, UTB, Stuttgart.

Grözinger, A., 1991, 'Sprache und Bild. Auf dem Weg zu einer elementar-theologischen Hermeneutik', in D. Zilleßen, S. Alkier, R. Koerrenz \& H. Schroeter (Hg.), Praktischtheologische Hermeneutik, Ansätze - Anregungen - Aufgaben, pp. 45-57, CMZ, Rheinbach-Merzbach.

Grözinger, A., 2008, Homiletik, Gütersloher Verlagshaus, Gütersloh.

Heimbrock, H., 1993, Gottesdienst: Spielraum des Lebens, Deutscher Studien, Weinheim.

Hermelink, J., 2007, ‘Gottesdienst aus Sicht der Leute. Ein Überblick über neuere Forschungsergebnisse', Zeitschrift der Gemeinsame Arbeitsstelle für gottesdienstliche Fragen der EKD 3, 5-14.

Klie, T. \& Leonhard, S. (Hg.), 2008, Performative Religionsdidaktik. Religionsästhetik Lernorte - Unterrichtspraxis, Kohlhammer, Stuttgart.

Kloppers, E., 2003, 'Die erediens as “Gesamtkunstwerk"', Nederduitse Gereformeerde Teologiese Tydskrif 44 (1/2), 80-88.

Kloppers, E., 2010, 'Tyd as gawe - God se tyd: Die polsslag van die Kerkjaar', Acta Theologica 30(2), 50-66. http://dx.doi.org/10.4314/actat.v30i2.67263

Kloppers, W., 2003a, 'Wanneer die beelde uit die oog geneem word. Teks en beeld: 'n Teologiese probleem', HTS Teologiese Studies/Theological Studies 59(1), 85-97. http://dx.doi.org/10.4102/hts.v59i1.647

Kloppers, W., 2003b, 'Ervaringsgeoriënteerde geloofsoordrag: geloofwaardige waarheid', Verbum et Ecclesia 24(1), 104-112. http://dx.doi.org/10.4102/ve. v24i1.315

Kloppers, W., 2003c, 'Die Kerkjaar en liturgiese kleure', Vir die Musiekleier 30, 22-28. 
Kloppers, W., 2006, 'Die Rembrandt-kode: God se lig in die donker van die mens se lewe', Konteks, Okt, 8-11.

Kloppers, W., 2013, 'Wie verduister God se lig? Simboliese kommunikasie in die Pietà van Boris Israiljewitsch Anisfeld (1879-1973)', THT 2, 26-38.

Martin, G.M., 1984, 'Predigt als "offenes Kunstwerk"? Zum Dialog zwischen Homiletik und Rezeptionsästhetik', Evangelische Theologie 44, 46-58.

Naumann, B., 2013, Heilige Orte und heilige Zeiten? Kirchenräume und Kirchenjahr. Theologie für die Gemeinde, Evangelische Verlagsanstalt, Leipzig.

Pohl-Patalong, U., 2011, Gottesdienst erleben. Empirische Einsichten zum evangelischen Gottesdienst, Kohlhammer, Stuttgart.

Raschzok, K. 2003, 'Kirchenbau und Kirchenraum', in H. Schmidt-Lauber, M. MeyerBlanck \& K-H. Bieritz ( $\mathrm{Hg}$.), 3. Auflage, Handbuch der Liturgik-Liturgiewissenschaft in Theologie und Praxis, pp. 391-412, Vandenhoeck, Göttingen.

Rupp, H. (Hg.), 2006, Handbuch der Kirchenpädagogik. Kirchenräume wahrnehmen, deuten und erschließen, Kohlhammer, Stuttgart.

Schwier, H., 2010, 'Zur Sache der Texte. Bibel, Predigt und Hermeneutik aus exegetischer Sicht', in A. Deeg \& M. Nicol (Hg.), Bibelwort und Kanzelsprache. Homiletik und Hermeneutik im Dialog, pp. 11-29, EVA, Leipzig.

Schwier, H., 2014, 'Der Fensterzyklus von Johannes Schreiter in der Peterskirche Heidelberg', Geistreich, Besoek 15 December 2014, from http://www.geistreich. de/experience_reports/2148?c=2
Stückelberger, J., 2011, 'Funktionaler oder sakraler Raum? Kirche als funktionaler Raum', in R. Kunz, A. Marti \& D. Plüss (eds.), Reformierte Liturgik - Kontrovers, pp. 219-228, TVZ, Zürich.

Sundermeier, T. \& Schwier, H., 2013, 'Heiliger Geist', in H. Schwier (Hg.), Botschaften aus Licht und Glas. Der Fensterzyklus von Johannes Schreiter in der Heidelberger Universitätskirche, pp. 64-68, Schnell \& Steiner, Regensburg.

Ulrichs, H-U., 2013, Bilder predigen, Vandenhoeck \& Ruprecht, Göttingen.

Van der Merwe, H., 2013, 'Loodglasvensters vir ons kerkgebou', Polsslag 9, 25.

Van der Merwe, H., 2014, 'Ons loodglasvensters. In die pylvak van die grootse projek', Polsslag 13, 6- 7 .

Van der Merwe, K., 2014, 'Die metaforiese verkondiging van die loodglasvensters by NHKA Pretoria-Oos', Werkstuk vir Praktykvorming, November.

Volp, R., 1991, 'Ästhetik als Anfrage gegenüber einer Kirche in der Defensive. Beobachtungen zum Gestaltungsproblem der Religion', in D. Zilleßen, S. Alkier, R. Koerrenz \& H. Schroeter (Hg.), Praktisch-theologische Hermeneutik, AnsätzeAnregungen - Aufgaben, pp. 277-294, CMZ, Rheinbach-Merzbach.

Wegenast, K., 1991, 'Hermeneutik und Didaktik', in D. Zilleßen, S. Alkier, R. Koerrenz \& H. Schroeter (Hg.), Praktisch-theologische Hermeneutik, Ansätze - Anregungen Aufgaben, pp. 23-43, CMZ, Rheinbach-Merzbach, besigtig 15 Desember 2014, by http://de.wikipedia.org/wiki/Glasmalere 